National

Institute for

Commodity

April 1997

Promotion

NICPRE 97-02

Research \&

Evaluation

R.B. $97-06$

\title{
An Economic Analysis of Generic \\ Milk Advertising Impacts on \\ Markets in New York State
}

by

John Lenz

Harry M. Kaiser

and

Chanjin Chung 


\section{The National Institute For Commodity Promotion Research and Evaluation}

The National Institute for Commodity Promotion Research and Evaluation was initially funded by a CSRS Special Grant in April 1994. The Institute is an offshoot of The Committee on Commodity Promotion Research (NEC-63). A component of the Land Grant committee structure to coordinate research in agriculture and related fields, NEC-63 was established in 1985 to foster quality research and dialogue on the economics of commodity promotion.

The Institute's mission is to enhance the overall understanding of economic and policy issues associated with commodity promotion programs. An understanding of these issues is crucial to ensuring continued authorization for domestic checkoff programs and to fund export promotion programs. The Institute supports specific research projects and facilitates collaboration among administrators and researchers in government, universities, and commodity promotion organizations. Through its sponsored research and compilations of related research reports, the Institute serves as a centralized source of knowledge and information about commodity promotion economics.

The Institute is housed in the Department of Agricultural, Resource, and Managerial Economics at Cornell University in Ithaca, New York as a component of the Cornell Commodity Promotion Research Program.

\section{Institute Objectives}

- Support, coordinate, and conduct studies to identify key economic relationships and assess the impact of domestic and export commodity promotion programs on farmers, consumers, and the food industry.

- Develop and maintain comprehensive databases relating to commodity promotion research and evaluation.

- Facilitate the coordination of multi-commodity and multi-country research and evaluation efforts.

- Enhance both public and private policy maker's understanding of the economics of commodity promotion programs.

- Facilitate the development of new theory and research methodology. 


\title{
An Economic Analysis of Generic Milk Advertising Impacts on Markets in New York State
}

\author{
John Lenz, Harry M. Kaiser, and Chanjin Chung*
}

\section{$\underline{\text { Introduction }}$}

During 1995, New York dairy farmers marketed 11.5 billion pounds of milk. Under the Dairy and Tobacco Adjustment Act of 1983, the federal enabling legislation for U.S dairy promotion programs, New York dairy farmers contributed $\$ 17.2$ million $^{1}$ in 1995 into federally-authorized dairy promotion and advertising funds. These contributions, in the form of mandatory "checkoffs" when milk is commercially marketed, are allocated not only to the national program, ${ }^{2}$ but also to the regional, state, and local programs operating in markets where milk is ultimately sold. The federal legislation specifies that at least 5 cents of the 15 cent per hundredweight (cwt) checkoff must be allocated to the national program, and allows for credits of up to 10 cents per cwt for contributions to authorized regional, state, or local promotion programs. In 1995 , of the $\$ 17.2$ million paid by New York dairy farmers, just under $\$ 11.5$ million was allocated to regional, state, and local programs operating in the markets where New York milk is sold.

\footnotetext{
* John Lenz is a former research associate, Harry M. Kaiser is an associate professor and director of the Cornell Commodity Promotion Research Program, and Chanjin Chung is a research associate in the Department of Agricultural, Resource, and Managerial Economics at Cornell University. Funding for this project came from the New York State Dairy Promotion Order. The authors thank members of the New York Dairy Promotion Advisory Board for useful suggestions on earlier versions of this report, and Jennifer Ferrero for editorial comments.

'At the rate of 15 cents per hundredweight of milk marketed.

${ }^{2}$ Operated by Dairy Management, Incorporated (DMI).
} 
The largest regional program operating in New York state is the American Dairy Association and Dairy Council (ADADC). Other programs receiving financial support from New York dairy farmers include Milk for Health on the Niagara Frontier, which is located in the Buffalo area, and the Rochester Health Foundation. In addition, to the extent that New York milk flows to New England, Milk Promotion Services, Incorporated receives New York dairy farmers' financial support.

These advertising and promotion organizations are engaged in a wide range of promotional activities including nutrition education, various point-of-sale merchandising activities, and media advertising. The present study focuses solely on the media advertising activities in five New York markets--New York City, Albany, Syracuse, Rochester, and Buffalo. The majority of dairy checkoff funds in New York state are invested in media advertising. Under contract with the New York Milk Promotion Advisory Board (NYMPAB), ADADC implements the advertising programs in the New York City, Albany, and Syracuse markets. Through a contractual relationship with the Rochester Health Foundation, ADADC places advertising in the Rochester market as well. Milk for Health on the Niagara Frontier operates an independent advertising program in the Buffalo market.

Beginning in 1990, advertising expenditures were significantly increased in the Syracuse market. Research conducted by Liu and Forker using data from the 1970s and 1980s indicated a significantly greater responsiveness to advertising in the Syracuse market compared to the responsiveness in the New York City and Albany markets. As a result of this finding, the NYMPAB directed ADADC to reallocate media advertising expenditures. The reallocation involved cutting New York City and Albany expenditures and nearly tripling Syracuse 
expenditures. This expenditure allocation has been in effect from 1990 through today. However, there has been no published analysis of advertising responsiveness in these markets since the Liu and Forker study.

The study reported in this paper provides an updated analysis on the responsiveness of fluid milk sales to milk advertising in the New York City, Albany, Syracuse, Rochester, and Buffalo markets. Given the expenditure reallocation that began in 1990, and the length of time that has passed since this was last studied, it is important to reexamine the relative responsiveness and rates of return associated with advertising among these markets. The following sections describe the conceptual fluid milk demand model used to evaluate advertising in the markets being analyzed, document the data collected for this analysis, discuss some specific issues related to model estimation, and report and interpret the econometric results. Finally, the econometric results are used to simulate the impacts of the New York state advertising program on the farm milk price and producer rates of returns for these five markets.

\section{The Model}

In each of the markets, per capita fluid milk sales are assumed to be affected not only by advertising expenditures, but also by the retail price of milk, prices of substitutes for milk, consumer income, consumer health concerns about dietary fat, and competing advertising expenditures for milk substitutes. In addition, the demand equation for each market incorporates a set of variables to account for seasonality in fluid milk consumption, and a set of yearly indicator variables to account for differences in sales between years. The general form for the demand equation for each market can be expressed as: 
Quantity $=f($ milk price, substitute price, income, dietary fat concerns, competing beverage advertising expenditures, generic milk advertising expenditures, seasonality, yearly indicators).

Regardless of the functional form chosen for estimation, economic theory provides a basis for expectations as to the signs of the price and income variables. With fluid milk quantity as the dependent variable, the estimated coefficient for fluid milk price should have a negative sign. In other words, the expected consumer response to an increase in the price of milk is lower consumption. When the price of a substitute for milk rises, making milk a relatively better buy, the effect should be to increase milk consumption. Thus, the estimated coefficient for any substitute price is expected to be positive. The estimated coefficient for income is expected to have a positive sign. When income rises, consumers can be expected to purchase more milk, as well as more of most goods.

One can also make reasonable hypotheses on the expected signs for the consumer fat concerns, competing advertising, and milk advertising variables. Since some fluid milk products have a relatively high fat content (e.g., whole milk), consumer concerns about dietary fat should depress milk consumption. Accordingly, the estimated coefficient on the consumer fat concerns variable should have a negative sign. Advertising of milk substitutes should also decrease milk consumption. Therefore, there should be an inverse relationship between competing advertising expenditures and milk consumption. If milk advertising is effective, an increase in milk advertising should be associated with greater milk consumption; thus estimated milk advertising coefficients should have positive signs when this advertising is working as intended. 


\section{Data}

For each of the five markets being analyzed, the relevant market area is assumed to be the dominant market area (DMA) for the television stations broadcasting from the major city in the market. In each market, this definition leads to a multi-county designation. Of the five markets included in this study, the New York City market is the only one in which a significant portion of the DMA lies outside the boundaries of New York state. The New York City DMA includes roughly the northern half of New Jersey--a multi-county area that coincides with the New Jersey portion of the New York-New Jersey Federal Milk Marketing Order (Order \#2). In the past, we have obtained fluid milk sales data for the New Jersey portion of the New York City DMA from the New Jersey Department of Agriculture, and more recently from the Market Administrator's Office for Order \#2. Unfortunately, data are no longer available from either of these sources. Therefore, in the present analysis of the New York City DMA, only the New York State portion is considered, and it is assumed that per capita milk sales in northern New Jersey are the same as per capita sales in New York City.

Fluid milk sales for each of the five markets are estimates based on data collected by the Division of Dairy Industry Services and Producer Security (DIS), New York State Department of Agriculture and Markets. Each year, in May and October, every plant and milk dealer with route sales in New York state must file a report showing the amounts of milk sold in each county in which they do business. In addition, all plants from which processed fluid milk is delivered to New York state dealers, or sold on routes in New York state, must file monthly plant reports. Based on these reports, it is possible to trace all milk sold into any designated market area back to the plants in which it was processed. Based on the May report, and the monthly plant reports 
for May, plant-specific allocation factors can be developed and applied to the monthly plant reports to estimate monthly in-market sales for January through June. Likewise, the October report provides the basis for estimating monthly in-market sales for July through December.

Fluid milk prices for each market come from the DIS publication titled Survey of Retail Milk Prices for Selected Markets in NYS. This report contains retail prices for each type of milk (whole, $2 \%, 1 \%$, and skim) in various container sizes for several cities in New York. The price series used in this analysis are for whole milk in half-gallon containers.

The Consumer Price Index (CPI) for nonalcoholic beverages in the Northeast is used as a proxy for the substitute price in each equation. This series is available in the CPI Detail Report published by the Federal Bureau of Labor Statistics. This same report is also the source for the CPI for all items which is used as a deflator for income.

The income measure used in this study is from the New York State Department of Labor's Employment Review. For each of the five markets being studied, this periodical contains timely reports of average weekly earnings of production workers in the manufacturing sector. Although a measure of per capita income would be preferable, reporting lags of several years on this data preclude its use here. Liu and Forker also used this variable as a proxy for consumer income.

The fat concern variable was included because consumer concerns about dietary fat were expected to be an important factor negatively associated with milk consumption. This variable was constructed by Ward based on a quarterly survey of 14,000 consumers nationwide conducted by the National Panel Diary (NPD) Group, which is a company that collects survey information on consumer behavior and attitudes. Since the survey was random, the 14,000 consumers in one 
quarter were not necessarily the same as the 14,000 consumers in the next quarter. Because this was a national survey, it was assumed that consumers in the New York state markets had identical behavior and attributes as consumers in the rest of the United States. Consumers were asked whether they completely agree, agree mostly, agree somewhat, neither agree nor disagree, disagree somewhat, disagree mostly, or completely disagree with the statement ... "a person should be cautious about the fat in one's diet." The fat concern variable was constructed based on the percentage of consumers expressing concern regarding this statement. To convert this variable from a quarterly to monthly basis, a linear interpolation procedure was used.

Nominal advertising expenditures for competing beverages were collected on a quarterly basis from Leading National Advertisers. The products included coffee and tea, bottled water, fruit and vegetable juices, carbonated beverages, and other nonalcoholic, non-dairy beverages. To adjust for inflation and seasonal change in media costs, these expenditures were deflated by the Media Cost Index. The resulting advertising expenditures, which are on a national basis, were then prorated on a population basis to obtain an estimate of the portion of the national advertising effort affecting each of the New York state markets. Finally, linear interpolation was used to translate this series from a quarterly to a monthly basis.

Monthly nominal advertising expenditures on radio and television in the New York City, Albany, Syracuse, and Rochester markets come from a report titled "Committed Recaps" which was previously provided by D'Arcy, Masius, Benton and Bowles, the advertising agency handling the fluid milk account. With the recent agency switch on the fluid milk account, these data are now provided by the Leo Burnett agency. Nominal radio and television expenditures in the Buffalo market are provided by DIS from audits of Milk for Health on the Niagara Frontier. 
For all five markets, adjustments are made to advertising expenditures to transform them into a measure of advertising effort. These adjustments account for not only year-to-year inflation in media costs, but also quarter-to-quarter variations in media costs within any year. Monthly national fluid milk advertising expenditures are supplied by Dairy Management, Inc.; these expenditures are deflated and prorated on a population basis to obtain an estimate of the portion of the national fluid milk advertising effort affecting each of the markets under study here.

\section{Estimation}

Because there is a high correlation between the retail fluid milk price and the nonalcoholic beverage price index, inclusion of these two variables separately in the model causes multicollinearity problems. To deal with this problem, a ratio of the retail milk price to the nonalcoholic beverage price index is used. A double-log equation of the form

$$
\begin{aligned}
& \ln \text { SALES }=\alpha_{0}+\alpha_{1} \ln (\text { PRICE/SUB })+\alpha_{2} \ln {\text { EARNINGS }+\alpha_{3} \ln \text { FAT }}^{\mathrm{m}} \mathrm{n} \quad \mathrm{p} \\
& +\sum_{\mathrm{i}=0}^{\mathrm{m}} \beta_{\mathrm{i}} \ln \text { BEVAD }_{\mathrm{l}-\mathrm{i}}+\sum_{\mathrm{j}=0} \omega_{\mathrm{j}} \ln \text { MILKAD }_{\mathrm{l}-\mathrm{j}}+\sum_{\mathrm{k}=1} \delta_{\mathrm{k}} \text { SEASON }_{\mathrm{k}} \\
& \underset{\mathrm{r}=1}{\mathrm{q}} \gamma_{\mathrm{r}} \text { YEARDUM }_{\mathrm{r}}
\end{aligned}
$$

is specified for each market. In this equation, SALES is per capita fluid milk sales, PRICE is the retail fluid milk price, SUB is the nonalcoholic beverage price index, EARNINGS is average weekly earnings deflated by the CPI for all items, FAT is the consumer fat concern index, $\mathrm{BEVAD}_{\mathrm{t}-\mathrm{i}}$ is a vector of deflated advertising expenditures for competing milk products in the current and previous months, MILKAD $\mathrm{t}_{\mathrm{t}-\mathrm{i}}$ is a vector of deflated generic milk advertising 
expenditures in the current and previous months, $\mathrm{SEASON}_{\mathrm{j}}$ is a vector of seasonality variables represented by the $\mathrm{i}$-th wave of the sine and cosine functions, and $\mathrm{YEARDUM}_{\mathrm{k}}$ is a vector of intercept dummy variables for various years in the sample.

The coefficients on all advertising variables are estimated with a second order polynomial distributed lag function with endpoint restrictions imposed. This approach is used to estimate the effect on current month sales of not only current month advertising, but also advertising in past months. This assumes that the impact of advertising is distributed over time rather than being limited to only the month that the advertising is aired, which is a common assumption (Liu and Forker, Kaiser and Reberte). The length of the lag for each market is determined by selecting the lag length which results in the best statistical fit for the model. Consequently, the models for all markets are the same with the possible exception of the number of lagged advertising variables.

One advantage of the double-log form is that it provides coefficient estimates that are direct estimates of elasticities. An estimated elasticity is a measure of the percentage change in the dependent variable, sales in this case, resulting from a 1 percent change in an independent variable. In the equation specified above, $\alpha_{1}$ is the own price elasticity (the elasticity of milk sales with respect to the milk price), $\alpha_{2}$ is the income elasticity (the elasticity of milk sales with respect to income), $\alpha_{3}$ is the consumer fat concerns elasticity (the elasticity of milk sales with respect to consumer fat concerns), and $\beta_{\mathrm{i}}$ and $\omega_{\mathrm{j}}$ are the competing and own advertising elasticities (the elasticity of milk sales with respect to competing beverage and milk advertising expenditures in the current and previous months).

In July and August of 1994, expenditures for national fluid milk advertising were zero. Since the logarithm of zero is undefined, a nominal expenditure of $\$ 1$ is specified for each of 
these two months so that the double-log model can be estimated.

\section{Econometric Results}

The model was initially estimated using several different specifications for the competing advertising variable, including advertising expenditures for carbonated beverage, fruit and vegetable juices, coffee and tea, bottled water, and all beverages combined. The specification that consistently was the most statistically significant in all markets was bottled water advertising, which was subsequently used to represent competing beverage advertising in the demand equations. The elasticity estimates of important economic variables are reported in Table 1. Table 2 presents the entire econometric estimates for the five markets, which were estimated using ordinary least squares.

The estimated coefficients on the traditional economic variables (e.g., price and income) were either not significantly different from zero, or relatively small in magnitude. For example, the retail price elasticity was only statistically significant in New York City (-0.133) and Albany $(-0.232)$, i.e., a 1 percent increase in price would have resulted in an average decrease in per capita sales of 0.133 and 0.232 percent in New York City and Albany, respectively. The relatively small magnitude or lack of statistically significant elasticities was consistent with virtually every previous study of New York state markets (see, for example, Kinnucan; Kinnucan and Forker; Kaiser and Reberte). The income variable was not statistically significant in any market. The negligible impact of price and income on per capita fluid milk sales was not surprising considering that milk is generally viewed as a staple good, i.e., changes in price or income have little impact on milk sales. 
Consumer concerns over dietary fat were negative and statistically significant in the Albany, Buffalo, and Rochester markets. The elasticity of per capita milk sales with respect to fat concerns ranged from -0.093 in New York City, to 0.324 in Rochester. This variable was the most important of all demand factors affecting per capita milk sales in Buffalo and Rochester, and the second most important variable in the other three markets. Therefore, it appears that milk consumption is significantly affected by consumer concerns about dietary fat. Furthermore, these results suggested that consumer health concerns should be measured and included in food demand equations since these concerns may be among the most important factors affecting food demand. Both sets of advertising variables were consistently statistically significant in all five markets (except for competing beverage advertising in Syracuse). The negative long run elasticity on competing beverage advertising indicated that milk and bottled water are substitutes. The positive and statistically significant long run elasticity of generic milk advertising indicated that advertising from 1986-95, on average, had a positive impact on per capita milk sales. Buffalo had the highest average long-run generic milk advertising elasticity of 0.085 , i.e., a 1 percent increase in generic milk advertising expenditure resulted in an average increase in per capita milk sales of 0.085 percent. $^{3}$ New York City was close behind with an average long-run advertising elasticity of 0.060 . This was followed by Syracuse $(0.041)$, Rochester $(0.022)$, and Albany (0.015). It is interesting that all New York state markets, except for Albany, had a higher generic milk advertising elasticity than the national average elasticity of 0.021 estimated by Kaiser.

\footnotetext{
${ }^{3}$ The estimated advertising elasticity for Buffalo may be biased upward for two reasons. First, there are some milk sales in this market from Canadians living over the border which are unaccounted for due to a lack of data. Second, there is some milk advertising from Ontario in this market which is not included in the demand equation. In future research, we will incorporate milk advertising expenditures from Ontario to lessen the potential bias in this market.
} 
It is also interesting that the advertising elasticities in all three markets that Liu and Forker considered (New York City, Syracuse, and Albany) have increased. Based on earlier data, Liu and Forker estimated average long-run generic milk advertising elasticities to be 0.015 , 0.020 , and 0.007 for New York City, Syracuse, and Albany, respectively. Their estimated elasticity in Albany was not statistically, significantly different from zero. Note that our estimates were 4.0,2.1, and 2.1 times higher than Liu and Forker's, suggesting two conclusions. First, advertising responsiveness in these markets appears to have grown in more recent years. Second, there was a much higher growth in advertising responsiveness in New York City compared to Syracuse, even though generic advertising expenditures were dramatically increased in Syracuse in the 1990s.

An interesting comparison is the relative impacts of milk advertising vs. competing beverage advertising on per capita milk sales. In Buffalo, New York City, and Syracuse the positive impact of generic milk advertising was larger than the negative impact of competing beverage advertising on per capita milk sales. In fact the ratio of the generic milk advertising elasticity to competing advertising elasticity was $4.7,2.4$, and 6.8 respectively, for Buffalo, New York City, and Syracuse. On the other hand, in Albany and Rochester, the positive impact of generic milk advertising was smaller than the negative impact of competing beverage advertising on per capita milk sales. In this case, the ratio of the generic milk advertising elasticity to competing advertising elasticity was 0.3 and 0.4 , respectively, for Albany and Rochester.

Impacts of New York State Advertising on Farm Prices and of Profits

The estimated model was used to simulate the impact of New York state generic milk advertising 
on producer prices and returns. The model was simulated under two advertising scenarios over the 1987-95 period: (1) with combined national and New York state milk advertising expenditures equal to historic monthly levels, and (2) with national milk advertising expenditures equal to historic levels, but no New York state advertising. A comparison of the results of the two scenarios provides a measure of the state program's impact on New York markets. The two bottom-line measures that New York dairy farmers are interested in are how state-level advertising impacts the blend (farm milk) price and whether the benefits of state-level advertising are greater than the costs in each of the five markets.

New York state dairy farmers invest 5 to 6 cents (in nominal terms) of their checkoff money for each hundredweight of milk marketed in local advertising. Assuming there is no supply response and no changes in Class I and Class II prices due to New York state advertising, the advertising impacts on blend price $(\Delta \mathrm{BP})$ are equal to:

$$
\begin{aligned}
& \Delta \mathrm{BP}=\mathrm{BP}_{a}-\mathrm{BP}_{0}=\frac{\left(\mathrm{P}^{\mathrm{II}}+\mathrm{DF}\right) \mathrm{Q}_{\mathrm{a}}^{\mathrm{I}}+\mathrm{P}^{\mathrm{II}}\left(\mathrm{Q}-\mathrm{Q}_{\mathrm{a}}^{\mathrm{I}}\right)}{\mathrm{Q}}-\frac{\left(\mathrm{P}^{\mathrm{II}}+\mathrm{DF}\right) \mathrm{Q}_{0}^{\mathrm{I}}+\mathrm{P}^{\mathrm{II}}\left(\mathrm{Q}-\mathrm{Q}_{0}^{\mathrm{I}}\right)}{\mathrm{Q}} \\
& =\frac{\left(\mathrm{P}^{\mathrm{II}}+\mathrm{DF}\right)\left(\mathrm{Q}_{\mathrm{a}}^{\mathrm{I}}-\mathrm{Q}_{0}^{1}\right)-\mathrm{P}^{\mathrm{II}}\left(\mathrm{Q}_{\mathrm{a}}^{\mathrm{I}}-\mathrm{Q}_{0}^{\mathrm{I}}\right)}{\mathrm{Q}}=\frac{\mathrm{DF} \bullet \Delta \mathrm{Q}^{\mathrm{I}}}{\mathrm{Q}}
\end{aligned}
$$

where $\mathrm{BP}_{\mathrm{a}}$ and $\mathrm{BP}_{0}$ are blend prices with and without New York state advertising expenditures; $\mathrm{Q}_{\mathrm{a}}{ }^{\mathrm{I}}, \mathrm{Q}_{0}{ }^{\mathrm{I}}, \mathrm{Q}$, and $\Delta \mathrm{Q}^{\mathrm{I}}$ are fluid milk sales with and without advertising, total milk sales, and change in fluid milk sales due to fluid milk advertising, respectively; and $\mathrm{P}^{\mathrm{II}}$ and DF are milk price in manufactured markets and Class I differential.

Table 3 presents the average increase in the blend price for Order $\# 2$ and the Western New York State (WNYS) Milk Marketing Order, and local fluid milk advertising costs in New York State. The increase in the blend price and the advertising costs are in 1986 dollars. Order 
\#2 includes the New York City, Syracuse, and Albany markets while the WNYS Order covers the Rochester and Buffalo markets. Between 1987 and 1995, local fluid milk advertising increased the blend prices of both marketing orders. Order \#2 and the WNYS Order blend prices increased by 8.52 and 9.77 cents per cwt, on average, while farmers invested 3.89 and 4.87 cents per cwt in fluid milk advertising for each market. This translates into a rate of return, or benefit cost ratio, of 2.19 for Order \#2 and 2.01 for the WNYS Order, i.e., an additional dollar spent on state generic milk advertising would have resulted in an average increase of $\$ 2.19$ and $\$ 2.01$, respectively, in Order \#2 and the WNYS Order.

Since a blend price is based on marketwide information, which is geographically larger than any of the five individual New York state cities considered in this study, the same procedures cannot be used to estimate a rate of return for each city. However, a different, but comparable method can be used to measure the impacts of New York state advertising for each market in terms of returns. The benefits of fluid milk advertising are the additional Class I revenues created by increasing fluid milk sales since milk going into fluid use receives a premium (Class I differential) compared to milk going into manufactured dairy products. Accordingly, the benefits in each market due to state milk advertising are equal to:

$$
\text { BENEFIT }=\mathrm{DF} * \triangle \mathrm{SALES} * \mathrm{POP},
$$

where BENEFIT is the monetary value of benefits in the market due to state-level advertising, $\triangle$ SALES is the change in per capita sales in the market due to state-level milk advertising, and POP is the market population. The benefits associated with New York state generic milk advertising were computed monthly from 1987 to 1995 by simulating the above two scenarios and taking the difference in per capita sales to obtain $\triangle$ SALES. To account for inflation, the 
Class I differential in each market was deflated by the CPI (in 1986 dollars). The cost in each market due to state milk advertising is the advertising cost. As was the case before, to account for inflation, advertising cost (COST) was deflated by the Media Cost Index (in 1986 dollars). A benefit-cost ratio, or rate of return, for state-level advertising in each market can then be calculated as:

$$
\mathrm{ROR}=\mathrm{BENEFIT} / \mathrm{COST} .
$$

Table 4 displays the estimated average rates of return to New York state generic milk advertising from 1987 to 1995 for the five markets and a weighted average for all five markets. It is clear from these findings that state spending on generic milk advertising over the period 1987-95 has been profitable for dairy farmers. The weighted average rate of return for the five markets was 2.35 , i.e., an additional dollar spent on state generic milk advertising resulted in an average increase of $\$ 2.35$ in Class I revenue.

In terms of individual New York state markets, New York City had the highest rate of return, which was followed closely by Buffalo. This result was similar to earlier findings by Thompson and Eiler, and Thompson using data from the 1970s. Liu and Forker, however, found that the rate of return was slightly higher in Syracuse than in New York City, and recommended increasing advertising in Syracuse threefold at the expense of a 10 percent reduction in advertising in New York City and Albany. But Liu and Forker did not consider the Buffalo market. The relative change in rates of return between New York City and Syracuse may be due to wearout in the Syracuse market and/or diminishing returns to advertising. Advertising levels in Syracuse were increased threefold in 1990, and maintained at this level ever since. Consequently, it is entirely reasonable to expect some erosion in the rate of return for this 
market. All of the markets, except for Albany, had rates of return above 1.00, indicating that the New York state contribution to the overall advertising program had benefits that exceeded costs, on average, over this period of time. While generic milk advertising was found to have a positive and statistically significant impact on per capita sales in Albany, the advertising elasticity was so low that benefits were lower than costs for this market.

The major policy implication of these results is that New York dairy farmers should consider some reallocation of advertising expenditures among markets. To determine an exact level of reallocation would require an optimization model, which was not considered in the current study but is planned in a future one. Nevertheless, the current results suggest some reduction of advertising in Albany, and perhaps in Rochester. The New York State Milk Promotion Board might also consider bringing advertising expenditures down in the Syracuse market and putting the excess from these reductions into New York City, which was the market with the highest rate of return.

\section{Conclusion}

The purpose of this study was to examine the responsiveness of fluid milk sales to milk advertising in the New York City, Albany, Syracuse, Rochester, and Buffalo markets. Given the expenditure reallocation that began in 1990, and the length of time that has passed since this was last studied, it is important to examine the relative responsiveness and rates of return associated with advertising among these markets. Fluid milk demand equations for New York City, Albany, Syracuse, Rochester, and Buffalo were estimated with monthly data for the period from January, 1986 through June, 1995. The demand equations included the following explanatory variables: retail milk price, nonalcoholic beverage price index, per capita weekly earnings in the 
manufacturing sector, consumer fat concerns index, bottled water advertising expenditures, generic milk advertising expenditures, seasonality variables, and annual indicator variables.

The results indicated that generic milk advertising was positive and statistically significant at the 10 percent significance level in each market. The highest advertising elasticity was in the Buffalo market, while the lowest was in Albany. The model was simulated to determine the impact of the New York state portion of advertising expenditures on producer milk prices and returns. The results indicated that Order $\# 2$ and the WNYS Order blend prices increased by 8.52 and 9.77 cents per cwt, on average, while farmers invested 3.89 and 4.87 cents per cwt (in 1986 dollars) in fluid milk advertising for each market. This translated into a rate of return, or benefit cost ratio of 2.19 for Order $\# 2$ and 2.01 for the WNYS Order, i.e., an additional dollar spent on state generic milk advertising would have resulted in an average increase of $\$ 2.19$ and $\$ 2.01$, respectively, in Order $\# 2$ and the WNYS Order. Rates of return were also estimated for each of the five markets. The weighted average rate of return for the five markets was 2.35 . In terms of individual New York state markets, New York City had the highest rate of return, which was followed closely by Buffalo. All of the markets, except for Albany, had rates of return above 1.00 , indicating that New York state's contribution to the overall advertising program had benefits that exceeded costs, on average, over this period of time. While generic milk advertising was found to have a positive and statistically significant impact on per capita sales in Albany, the advertising elasticity was so low that benefits were lower than costs for this market.

The major policy implication of these results is that New York dairy farmers should consider some reallocation of advertising expenditures among markets. The results suggest some 
reduction of advertising in Albany, and perhaps in Rochester. The New York State Milk Promotion Board might also consider bringing advertising expenditures down in the Syracuse market and putting the excess from these reductions into New York City, which was the market with the highest rate of return. 
Table 1. Selected elasticities, evaluated at sample means, for the five New York markets.

\begin{tabular}{lccccc}
\hline Variable & Albany & Buffalo & NYC & Rochester & Syracuse \\
\hline Price & $-0.232^{*}$ & 0.086 & $-0.135^{*}$ & -0.219 & -0.199 \\
Income & -0.185 & -0.172 & 0.014 & 0.148 & -0.139 \\
Fat concerns & $-0.183^{*}$ & $-0.245^{*}$ & -0.093 & $-0.324^{*}$ & -0.174 \\
Competing advertising & $-0.061^{*}$ & $-0.018^{*}$ & $-0.025^{*}$ & $-0.053^{*}$ & -0.006 \\
Milk advertising & $0.015^{*}$ & $0.085^{*}$ & $0.060^{*}$ & $0.022^{*}$ & $0.041^{*}$ \\
\hline
\end{tabular}

* Statistically significant from zero at the 10 percent level. 
Table 2. Estimation results for the per capita milk sales model for each market. ${ }^{1}$

\begin{tabular}{|c|c|c|c|c|c|}
\hline Variable & Albany & Buffalo & NYC & Rochester & Syracuse \\
\hline Constant & $\begin{array}{l}2.0952 \\
(2.99)\end{array}$ & $\begin{array}{l}2.6816 \\
(3.75)\end{array}$ & $\begin{array}{l}1.5661 \\
(3.99)\end{array}$ & $\begin{array}{l}1.5363 \\
(1.79)\end{array}$ & $\begin{array}{l}1.8308 \\
(2.19)\end{array}$ \\
\hline $\begin{array}{l}\text { Milk price/nonalcoholic } \\
\text { beverage price index }\end{array}$ & $\begin{array}{l}-0.2321 \\
(-1.80)\end{array}$ & $\begin{array}{l}0.0861 \\
(0.74)\end{array}$ & $\begin{array}{l}-0.1352 \\
(-1.91)\end{array}$ & $\begin{array}{r}-0.2185 \\
(-1.38)\end{array}$ & $\begin{array}{l}-0.1986 \\
(-1.16)\end{array}$ \\
\hline Average weekly earnings & $\begin{array}{r}-0.1845 \\
(-0.81)\end{array}$ & $\begin{array}{c}-0.1716 \\
(-1.10)\end{array}$ & $\begin{array}{l}0.0138 \\
(0.12)\end{array}$ & $\begin{array}{l}0.1476 \\
(0.92)\end{array}$ & $\begin{array}{c}-0.1392 \\
(-0.57)\end{array}$ \\
\hline Consumer fat concern & $\begin{array}{l}-0.1830 \\
(-1.44)\end{array}$ & $\begin{array}{r}-0.2451 \\
(-2.31)\end{array}$ & $\begin{array}{r}-0.0933 \\
(-1.19)\end{array}$ & $\begin{array}{r}-0.3237 \\
(-1.86)\end{array}$ & $\begin{array}{c}-0.1744 \\
(-0.93)\end{array}$ \\
\hline Generic milk advertising, $\mathrm{t}$ & $\begin{array}{l}0.0008 \\
(2.39)\end{array}$ & $\begin{array}{l}0.0091 \\
(2.14)\end{array}$ & $\begin{array}{l}0.0017 \\
(3.73)\end{array}$ & $\begin{array}{l}0.0018 \\
(1.55)\end{array}$ & $\begin{array}{l}0.0012 \\
(2.46)\end{array}$ \\
\hline Generic milk advertising, $\mathrm{t}-1$ & $\begin{array}{l}0.0015 \\
(2.39)\end{array}$ & $\begin{array}{l}0.0152 \\
(2.14)\end{array}$ & $\begin{array}{l}0.0032 \\
(3.73)\end{array}$ & $\begin{array}{l}0.0031 \\
(1.55)\end{array}$ & $\begin{array}{l}0.0022 \\
(2.46)\end{array}$ \\
\hline Generic milk advertising, $\mathrm{t}-2$ & $\begin{array}{l}0.0019 \\
(2.39)\end{array}$ & $\begin{array}{l}0.0182 \\
(2.14)\end{array}$ & $\begin{array}{l}0.0044 \\
(3.73)\end{array}$ & $\begin{array}{l}0.0039 \\
(1.55)\end{array}$ & $\begin{array}{l}0.0030 \\
(2.46)\end{array}$ \\
\hline Generic milk advertising, $\mathrm{t}-3$ & $\begin{array}{l}0.0022 \\
(2.39)\end{array}$ & $\begin{array}{l}0.0182 \\
(2.14)\end{array}$ & $\begin{array}{l}0.0053 \\
(3.73)\end{array}$ & $\begin{array}{c}0.0042 \\
(1.55)\end{array}$ & $\begin{array}{l}0.0036 \\
(2.46)\end{array}$ \\
\hline Generic milk advertising, $t-4$ & $\begin{array}{l}0.0023 \\
(2.39)\end{array}$ & $\begin{array}{l}0.0152 \\
(2.14)\end{array}$ & $\begin{array}{l}0.0060 \\
(3.73)\end{array}$ & $\begin{array}{c}0.0039 \\
(1.55)\end{array}$ & $\begin{array}{l}0.0041 \\
(2.46)\end{array}$ \\
\hline Generic milk advertising, $\mathrm{t}-5$ & $\begin{array}{c}0.0022 \\
(2.39)\end{array}$ & $\begin{array}{l}0.0091 \\
(2.14)\end{array}$ & $\begin{array}{c}0.0064 \\
(3.73)\end{array}$ & $\begin{array}{l}0.0031 \\
(1.55)\end{array}$ & $\begin{array}{c}0.0043 \\
(2.46)\end{array}$ \\
\hline Generic milk advertising, $\mathrm{t}-6$ & $\begin{array}{c}0.0019 \\
(2.39)\end{array}$ & & $\begin{array}{c}0.0065 \\
(3.73)\end{array}$ & $\begin{array}{c}0.0018 \\
(1.55)\end{array}$ & $\begin{array}{c}0.0044 \\
(2.46)\end{array}$ \\
\hline Generic milk advertising, $\mathrm{t}-7$ & $\begin{array}{c}0.0015 \\
(2.39)\end{array}$ & & $\begin{array}{c}0.0064 \\
(3.73)\end{array}$ & & $\begin{array}{c}0.0043 \\
(2.46)\end{array}$ \\
\hline Generic milk advertising, $\mathrm{t}-8$ & $\begin{array}{c}0.0008 \\
(2.39)\end{array}$ & & $\begin{array}{r}0.0060 \\
(3.73)\end{array}$ & & $\begin{array}{l}0.0041 \\
(2.46)\end{array}$ \\
\hline Generic milk advertising, t-9 & & & $\begin{array}{r}0.0053 \\
(3.73)\end{array}$ & & $\begin{array}{l}0.0036 \\
(2.46)\end{array}$ \\
\hline Generic milk advertising, $\mathrm{t}-10$ & & & $\begin{array}{c}0.0044 \\
(3.73)\end{array}$ & & $\begin{array}{c}0.0030 \\
(2.46)\end{array}$ \\
\hline
\end{tabular}




\begin{tabular}{|c|c|c|c|c|c|}
\hline Variable & Albany & Buffalo & NYC & Rochester & Syracuse \\
\hline Generic milk advertising, $\mathrm{t}-11$ & & & $\begin{array}{c}0.0032 \\
(3.73)\end{array}$ & & $\begin{array}{l}0.0022 \\
(2.46)\end{array}$ \\
\hline Generic milk advertising, $\mathrm{t}-12$ & & & $\begin{array}{l}0.0017 \\
(3.73)\end{array}$ & & $\begin{array}{l}0.0012 \\
(2.46)\end{array}$ \\
\hline $\begin{array}{l}\text { Sum of lagged generic milk } \\
\text { advertising coefficient }\end{array}$ & $\begin{array}{c}0.0152 \\
(2.39)\end{array}$ & $\begin{array}{c}0.0850 \\
(2.14)\end{array}$ & $\begin{array}{l}0.0603 \\
(3.73)\end{array}$ & $\begin{array}{c}0.0218 \\
(1.55)\end{array}$ & $\begin{array}{l}0.0411 \\
(2.46)\end{array}$ \\
\hline Competing advertising, $\mathrm{t}$ & $\begin{array}{r}-0.0033 \\
(-3.97)\end{array}$ & $\begin{array}{c}-0.0019 \\
(-2.02)\end{array}$ & $\begin{array}{r}-0.0007 \\
(-2.10)\end{array}$ & $\begin{array}{r}-0.0044 \\
(-3.21)\end{array}$ & $\begin{array}{l}-0.0002 \\
(-0.18)\end{array}$ \\
\hline Competing advertising, $\mathrm{t}-1$ & $\begin{array}{l}-0.0059 \\
(-3.97)\end{array}$ & $\begin{array}{l}-0.0032 \\
(-2.02)\end{array}$ & $\begin{array}{l}-0.0013 \\
(-2.10)\end{array}$ & $\begin{array}{l}-0.0075 \\
(-3.21)\end{array}$ & $\begin{array}{l}-0.0003 \\
(-0.18)\end{array}$ \\
\hline Competing advertising, $\mathrm{t}-2$ & $\begin{array}{l}-0.0078 \\
(-3.97)\end{array}$ & $\begin{array}{l}-0.0038 \\
(-2.02)\end{array}$ & $\begin{array}{l}-0.0018 \\
(-2.10)\end{array}$ & $\begin{array}{l}-0.0094 \\
(-3.21)\end{array}$ & $\begin{array}{l}-0.0005 \\
(-0.18)\end{array}$ \\
\hline Competing advertising, $\mathrm{t}-3$ & $\begin{array}{c}-0.0089 \\
(-3.97)\end{array}$ & $\begin{array}{l}-0.0038 \\
(-2.02)\end{array}$ & $\begin{array}{l}-0.0021 \\
(-2.10)\end{array}$ & $\begin{array}{c}-0.0100 \\
(-3.21)\end{array}$ & $\begin{array}{c}-0.0006 \\
(-0.18)\end{array}$ \\
\hline Competing advertising, $\mathrm{t}-4$ & $\begin{array}{r}-0.0093 \\
(-3.97)\end{array}$ & $\begin{array}{r}-0.0032 \\
(-2.02)\end{array}$ & $\begin{array}{r}-0.0024 \\
(-2.10)\end{array}$ & $\begin{array}{r}-0.0094 \\
(-3.21)\end{array}$ & $\begin{array}{c}-0.0006 \\
(-0.18)\end{array}$ \\
\hline Competing advertising, $\mathrm{t}-5$ & $\begin{array}{r}-0.0089 \\
(-3.97)\end{array}$ & $\begin{array}{c}-0.0019 \\
(-2.02)\end{array}$ & $\begin{array}{l}-0.0026 \\
(-2.10)\end{array}$ & $\begin{array}{l}-0.0075 \\
(-3.21)\end{array}$ & $\begin{array}{l}-0.0007 \\
(-0.18)\end{array}$ \\
\hline Competing advertising, $\mathrm{t}-6$ & $\begin{array}{l}-0.0078 \\
(-3.97)\end{array}$ & & $\begin{array}{l}-0.0026 \\
(-2.10)\end{array}$ & $\begin{array}{l}-0.0044 \\
(-3.21)\end{array}$ & $\begin{array}{r}-0.0007 \\
(-0.18)\end{array}$ \\
\hline Competing advertising, $\mathrm{t}-7$ & $\begin{array}{r}-0.0059 \\
(-3.97)\end{array}$ & & $\begin{array}{l}-0.0026 \\
(-2.10)\end{array}$ & & $\begin{array}{r}-0.0007 \\
(-0.18)\end{array}$ \\
\hline Competing advertising, $\mathrm{t}-8$ & $\begin{array}{l}-0.0033 \\
(-3.97)\end{array}$ & & $\begin{array}{c}-0.0024 \\
(-2.10)\end{array}$ & & $\begin{array}{c}-0.0006 \\
(-0.18)\end{array}$ \\
\hline Competing advertising, $\mathrm{t}-9$ & & & $\begin{array}{c}-0.0021 \\
(-2.10)\end{array}$ & & $\begin{array}{c}-0.0006 \\
(-0.18)\end{array}$ \\
\hline Competing advertising, $\mathrm{t}-10$ & & & $\begin{array}{c}-0.0018 \\
(-2.10)\end{array}$ & & $\begin{array}{c}-0.0005 \\
(-0.18)\end{array}$ \\
\hline Competing advertising, $\mathrm{t}-11$ & & & $\begin{array}{c}-0.0013 \\
(-2.10)\end{array}$ & & $\begin{array}{c}-0.0003 \\
(-0.18)\end{array}$ \\
\hline
\end{tabular}




\begin{tabular}{|c|c|c|c|c|c|}
\hline Variable & Albany & Buffalo & NYC & Rochester & Syracuse \\
\hline Competing advertising, $\mathrm{t}-12$ & & & $\begin{array}{l}-0.0007 \\
(-2.10)\end{array}$ & & $\begin{array}{c}-0.0002 \\
(-0.18)\end{array}$ \\
\hline $\begin{array}{l}\text { Sum of lagged competing } \\
\text { advertising coefficient }\end{array}$ & $\begin{array}{c}-0.0614 \\
(-3.97)\end{array}$ & $\begin{array}{c}-0.0179 \\
(-2.02)\end{array}$ & $\begin{array}{l}-0.0243 \\
(-2.10)\end{array}$ & $\begin{array}{r}-0.0526 \\
(-3.21)\end{array}$ & $\begin{array}{c}-0.0064 \\
(-0.18)\end{array}$ \\
\hline $\operatorname{Cos} 1$ & $\begin{array}{l}0.0892 \\
(7.33)\end{array}$ & $\begin{array}{l}0.0522 \\
(9.95)\end{array}$ & $\begin{array}{r}0.0331 \\
(6.30)\end{array}$ & $\begin{array}{l}0.0810 \\
(6.78)\end{array}$ & $\begin{array}{l}0.0550 \\
(3.74)\end{array}$ \\
\hline $\operatorname{Cos} 2$ & & $\begin{array}{c}-0.0058 \\
(-1.00)\end{array}$ & $\begin{array}{r}0.0025 \\
(0.70)\end{array}$ & & \\
\hline $\operatorname{Cos} 3$ & $\begin{array}{l}0.0247 \\
(4.76)\end{array}$ & $\begin{array}{c}0.0148 \\
(2.91)\end{array}$ & $\begin{array}{l}0.0089 \\
(2.70)\end{array}$ & $\begin{array}{l}0.0123 \\
(2.03)\end{array}$ & $\begin{array}{l}0.0077 \\
(1.32)\end{array}$ \\
\hline $\operatorname{Cos} 4$ & $\begin{array}{c}0.0198 \\
(4.18)\end{array}$ & $\begin{array}{l}0.0165 \\
(3.65)\end{array}$ & $\begin{array}{l}0.0115 \\
(3.43)\end{array}$ & $\begin{array}{l}0.0125 \\
(2.40)\end{array}$ & $\begin{array}{l}0.0162 \\
(3.08)\end{array}$ \\
\hline $\operatorname{Cos} 5$ & $\begin{array}{c}0.0146 \\
(3.28)\end{array}$ & $\begin{array}{c}0.0142 \\
(4.15)\end{array}$ & $\begin{array}{l}0.0066 \\
(2.00)\end{array}$ & $\begin{array}{l}0.0065 \\
(1.39)\end{array}$ & $\begin{array}{l}0.0061 \\
(1.38)\end{array}$ \\
\hline $\operatorname{Cos} 6$ & $\begin{array}{l}-0.0061 \\
(-2.06)\end{array}$ & $\begin{array}{l}-0.0044 \\
(-2.00)\end{array}$ & $\begin{array}{c}-0.0074 \\
(-3.24)\end{array}$ & & $\begin{array}{r}-0.0097 \\
(-3.32)\end{array}$ \\
\hline $\operatorname{Sin} 1$ & $\begin{array}{c}-0.0358 \\
(-3.81)\end{array}$ & $\begin{array}{r}-0.0175 \\
(-1.58)\end{array}$ & $\begin{array}{l}0.0135 \\
(3.69)\end{array}$ & $\begin{array}{r}-0.0400 \\
(-2.31)\end{array}$ & \\
\hline $\operatorname{Sin} 2$ & $\begin{array}{r}-0.0202 \\
(-3.52)\end{array}$ & $\begin{array}{r}-0.0245 \\
(-4.67)\end{array}$ & $\begin{array}{r}-0.0277 \\
(-8.49)\end{array}$ & $\begin{array}{r}-0.0304 \\
(-4.11)\end{array}$ & $\begin{array}{r}-0.0371 \\
(-4.75)\end{array}$ \\
\hline $\operatorname{Sin} 3$ & & $\begin{array}{c}0.0091 \\
(1.88)\end{array}$ & $\begin{array}{c}0.0040 \\
(1.27)\end{array}$ & $\begin{array}{c}0.0181 \\
(3.11)\end{array}$ & $\begin{array}{c}0.0132 \\
(2.35)\end{array}$ \\
\hline $\operatorname{Sin} 4$ & $\begin{array}{c}0.0071 \\
(1.58)\end{array}$ & $\begin{array}{l}0.0105 \\
(2.64)\end{array}$ & $\begin{array}{c}0.0145 \\
(4.63)\end{array}$ & $\begin{array}{l}0.0095 \\
(1.89)\end{array}$ & \\
\hline $\operatorname{Sin} 5$ & $\begin{array}{l}0.0305 \\
(7.33)\end{array}$ & $\begin{array}{c}0.0214 \\
(6.70)\end{array}$ & $\begin{array}{l}0.0251 \\
(7.96)\end{array}$ & $\begin{array}{c}0.0214 \\
(4.64)\end{array}$ & $\begin{array}{c}0.0244 \\
(5.81)\end{array}$ \\
\hline D87 & $\begin{array}{c}0.0704 \\
(3.28)\end{array}$ & & & & \\
\hline D88 & $\begin{array}{c}0.0627 \\
(3.20)\end{array}$ & & $\begin{array}{c}-0.0069 \\
(-0.77)\end{array}$ & & $\begin{array}{c}0.0180 \\
(0.55)\end{array}$ \\
\hline
\end{tabular}




\begin{tabular}{lccccc}
\hline Variable & Albany & Buffalo & NYC & Rochester & Syracuse \\
\hline D89 & 0.0425 & 0.0874 & 0.0135 & & 0.0361 \\
& $(2.52)$ & $(7.03)$ & $(1.34)$ & & $(1.13)$ \\
D90 & 0.1092 & 0.0693 & 0.0229 & 0.0906 & 0.0740 \\
& $(5.16)$ & $(3.20)$ & $(1.81)$ & $(2.96)$ & $(2.19)$ \\
& & & & & \\
D91 & 0.0330 & 0.0464 & 0.0395 & 0.0761 & \\
& $(1.65)$ & $(2.32)$ & $(2.79)$ & $(3.07)$ & \\
D92 & & 0.0252 & & & \\
& & $(1.58)$ & & & \\
D93 & 0.0313 & 0.0532 & -0.0202 & & \\
& $(1.60)$ & $(3.60)$ & $(-1.76)$ & & \\
D94 & & & -0.0369 & & \\
Adjusted R square & 0.7250 & 0.7379 & 0.8065 & 0.6332 & 0.6489 \\
Durbin Watson & 1.9280 & 1.9490 & 1.8680 & 2.1480 & 2.1850 \\
\hline
\end{tabular}

${ }^{1}$ Numbers in parentheses are t-statistics, based on the number of observations used for equation estimation--an estimated t-statistic of 1.282 or above indicates statistical significance in this study at the 10 percent significance level. 
Table 3 Advertising impacts on blend price. ${ }^{1}$

\begin{tabular}{lccc}
\hline Marketing Order & $\begin{array}{c}\text { Increase in blend price } \\
\text { (cents/cwt.) }\end{array}$ & $\begin{array}{c}\text { Advertising cost } \\
\text { (cents/cwt.) }\end{array}$ & Rate of return \\
\hline Federal Order \#2 & 8.52 & 3.89 & 2.19 \\
Western New York State Order & 9.77 & 4.87 & 2.01 \\
\hline
\end{tabular}

${ }^{1}$ The increase in blend price and advertising cost are in 1986 dollars (deflated by Media Cost Index) for each hundredweight of total milk marketed. 
Table 4. Rates of return to New York state generic milk advertising, evaluated at sample means, for the five New York markets.

Albany Buffalo NYC Rochester Syracuse Market average

$\begin{array}{lllllll}\text { Rate of return } & 0.68 & 2.62 & 2.77 & 1.18 & 1.28 & 2.35\end{array}$




\section{References}

Kaiser, H.M. "Impact of National Dairy Advertising on Dairy Markets, 1984-95." Journal of Agricultural and Applied Economics. Forthcoming, 1997.

Kaiser, H.M. and J.C. Reberte. "Impact of Generic Fluid Milk Advertising on Whole, Lowfat, and Skim Milk Demand." Journal of Dairy Science. 79(1996):2284-91.

Kinnucan, H. W. Demographic Versus Media Advertising Effects on Milk Demand: The Case of the New York City Market. Northeastern Journal Agricultural Economics. $15:(1986) 66$.

Kinnucan, H. W. and O. D. Forker. "Seasonality in the Consumer Response to Milk Advertising With Implications for Milk Promotion Policy." American Journal of Agricultural Economics 68(1986):562.

Leading National Advertisers, Inc. 1975-95. AD \& Summary. New York.

Liu, D.J. and O.D. Forker. "Optimal Control of Generic Fluid Milk Advertising Expenditures." American Journal of Agricultural Economics. 72(1990)1047-55.

Thompson, S. R. "Sales Response to Generic Promotion Efforts and Some Implications of Milk Advertising on Economic Surplus." Journal of the Northeastern Agricultural Economics Council. 3(1974):78.

Thompson, S. R. and D. A. Eiler. "Producer Returns from Increased Milk Advertising." American Journal of Agricultural Economics. 57(1975):505.

Ward, R. W. "Economic Returns From the Beef Checkoff." UF\#NCA94.1, National Cattlemen's Association, 1994. 
ORDER NO.

No. $96-18$

No. $96-19$

No. $96-20$

No. $97-01$

No. $97-02$

No. $97-03$

No. $97-04$

No. 97-05
TITLE

Rural Utility Service's Water and Waste Disposal Loan and Grant Program and its Contribution to Small Public Water System Improvements in New York State

A Theory of Nonprice Export Promotion with Application to USDA's Subsidy Programs

Assessing the Effectiveness of MPP Meat Advertising and Promotion in the Japanese Market

The Implications of Trade Liberalization for Federal Milk Marketing Orders

Information Needs of Agricultural Exporters: Results from a Focus Group Series

An Analysis of Processing and Distribution Productivity and Costs in 35 Fluid Milk Plants

Cornell Commodity Promotion Research Program: Summary of Recent Research Projects

The Economics of Replanting Generic Wine Grape Varieties in New York

\section{$\underline{\mathrm{AUTHOR}(\mathrm{S})}$}

Todd M. Schmit

Richard N. Boisvert

Henry W. Kinnucan Hui Xiao

Allison Comeau Ron C. Mittelhammer Thomas I. Wahl

Phillip M. Bishop Andrew M. Novakovic

Deborah Streeter Nelson Bills Jane Maestro-Scherer Rob Neenan

Eric M. Erba Richard D. Aplin Mark W. Stephenson

Harry M. Kaiser Jennifer L. Ferrero

Gerald B. White Barry Shaffer Robert M. Pool Alejandro Lalor 